\title{
Notas de leitura
}

FÁVERO, Maria de Lourdes de Albuquerque, BRITTO, Jader de Medeiros (orgs.). Dicionário de Educadores no Brasil: da Colônia aos dias atuais. $2^{\mathrm{a}}$ ed. aumentada. Rio de Janeiro: Editora UFRJ \& MEC/INEP/COMPED, 2002, 1008 p.

Desde a primeira edição do Dicionário de Educadores no Brasil: da colônia aos dias atuais, em 1999, seus organizadores assinalaram que a idéia do mesmo “...surgiu das dificuldades encontradas por professores, pesquisadores e estudantes ante a falta de informações sobre as matrizes do pensamento nessa área de trabalho, como também sobre a ação criadora empreendida por esses agentes do processo de desenvolvimento educacional no país..." (p. 23). A nova edição testemunha a boa acolhida que a comunidade acadêmica do campo educacional deu à obra. Sem dúvida, a iniciativa veio preencher considerável lacuna em nossa bibliografia.

Cabe reconhecer que, no domínio educacional, não tem sido muito freqüente a elaboração de obras básicas resultantes de pesquisas instrumentais que, sem fornecer construções e elaborações teóricas, circunscrevem sua ambição a paciente e generoso trabalho de ordenação de informações e sistematizações de análises fundamentais para auxiliar os estudos de outros investigadores. Decerto, nos últimos anos, e após a primeira edição do Dicionário, iniciativas congêneres, como as de edições de guias de fontes e catálogos de legislação, também puderam ser saudadas como contributos à pesquisa educacional. Mas, ainda estamos distantes da situação ideal na qual a maioria das investigações em diferentes territórios temáticos do campo educacional pudessem iniciarse pelo recurso a esses referentes básicos para o conhecimento.

Os dados técnicos da publicação do Dicionário informam sobre a ação conjunta da Editora da Universidade Federal do Rio de Janeiro (UFRJ), do Comitê dos Produtores da Informação Educacional (COMPED) e do Instituto Nacional de Estudos e Pesquisas Educacionais (INEP), no âmbito do Programa de Publicações e Apoio à Formação Inicial e Continuada de Professores. Tal parceria configura-se, no caso, como exemplar, esperando-se apenas que tenha poder proliferativo a bem dos empreendimentos bibliográficos e da circulação de saberes nos domínios educacionais. Deve ser ressaltado ainda o papel fundamental do Programa de Estudos e Documentação Educação e Sociedade (PROEDES), da UFRJ, responsável pela idéia e pela elaboração da obra - um dos projetos de sua linha de pesquisa sobre o pensamento educacional brasileiro.
Também é de caráter exemplar a marca de pluralidade da obra, observável na forma generosa, confiante e bem sucedida pela qual abriga colaborações de intelectuais de todos os pontos do país e em diferentes etapas da formação e carreiras acadêmicas. As diversidades de origem geográfica e institucional permitem assim uma miríade de perspectivas e ênfases bastante férteis na reconstrução de contribuições e obras relativas ao pensamento e aos processos educacionais brasileiros. Ainda sobre o modo de produção do Dicionário, seus organizadores chamam a atenção para as diretrizes de composição obedecidas, na escrita dos textos, e que incluem:

a) dados sobre a história pessoal - nome completo, data e local de nascimento e falecimento; b) dados relativos à vida profissional - experiência de magistério, funções exercidas na administração educacional, produção acadêmico-científica na área, abrangendo estudos, pesquisas, livros, capítulos de livros, artigos, pareceres, relatórios etc.; c) análise da contribuição do educador ao desenvolvimento do país. (p. 24)

Tais são as informações básicas encontráveis no Dicionário a propósito 
de 144 educadores dos vários estados brasileiros desde o período colonial até os dias de hoje. Da primeira para a segunda edição foram incluídos os perfis de setenta novos educadores e manteve-se o critério de abrigar apenas aqueles já falecidos, considerando-se como dizem os organizadores "que a obra por eles realizada se concluiu com o termo de sua existência”. Sábia decisão que, certamente, minimiza a controvérsia estéril que poderia ser desencadeada por eventuais ausências de indivíduos ainda atuantes.

Dentre as inúmeras potencialidades do recurso à obra, algumas são assinaladas por Maria de Lourdes de Albuquerque Fávero e Jader de Medeiros Brito, em sua apresentação à segunda edição. As observações dos organizadores dirigem a atenção dos leitores, simultaneamente, para as virtudes informativas dos verbetes, para modos possíveis de leitura e para peculiaridades que, eventualmente, ainda podem ser objeto de discussão e de retomadas e esse é o caso da seguinte advertência: "Outro aspecto a ressaltar é a presença das mulheres, elevando-se nesta edição ao total de 23 verbetes". Poderíamos indagar sobre o fato de serem poucas mulheres diante do número total de educadores inclusos no Dicionário, ou poderíamos considerar o número razoável pelo fato das mulheres terem tido pouca visibilidade nos quadros mais legítimos do campo educacional ou poderíamos ainda, como o tom e as palavras dos organizadores parecem permitir entender, sentirmo-nos desafiados - enquanto estudiosos de história da educação - a colaborar na superação desses limites, certamente provisórios das presenças e ausências dos educadores e educadoras na obra.

A coexistência de várias possibilidades de leitura é exemplificada pelos organizadores ao assinalarem incursões que privilegiem proximidades temporais (períodos da história da

educação), afinidades disciplinares e temáticas (filosofia, sociologia ou psicologia da educação), ou ainda vizinhanças institucionais e geográficas. Em qualquer das hipóteses, é inegável a riqueza das informações às quais se tem acesso. Se é fato que as contribuições acadêmicas valem tanto pelo que mostram, e pelo que são quanto pelo que potencializam, estamos diante de uma obra que, para além do que mostra também configura plataformas para outros trabalhos da mesma natureza: obras de referência que ensejam análises com base em um trânsito mais produtivo entre os agentes, o campo educacional e os conhecimentos específicos da área, as idéias e as políticas, as teorias e as práticas. A obra potencializa mesmo o desejo de se ver multiplicada a iniciativa de produções congêneres: catálogos biobibliográficos da área, guias de bibliotecas pedagógicas, repertórios da imprensa especializada em educação... novas contribuições para fecundar pesquisas.

Denice Barbara Catani

Faculdade de Educação da Universidade de São Paulo

ARCE, Alessandra. A pedagogia na "era
das revoluções": uma análise do
pensamento de Pestalozzi e Froebel.
Campinas: Autores Associados,
2002, 228 p.

A "era das revoluções" a que se refere o título desse livro advém de Eric Hobsbawm e circunscreve o período de 1789 a 1845, quando ocorreu a Revolução Francesa e quando a Revolução Industrial parecia determinar a forma triunfal e definitiva do capitalismo europeu. Foi também a época da intensificação dos movimentos sociais que pas- saram a reivindicar o cumprimento das promessas feitas pela burguesia - liberdade, igualdade e fraternidade - e que resultaram nos primeiros levantes operários. Foi nesse conturbado contexto que viveram Johann Heinrich Pestalozzi e Friedrich August Froebel, responsáveis por formulações que exerceram sensível influência sobre o pensamento pedagógico e a prática dos educadores nos séculos XIX e XX, com repercussões até a atualidade.

O livro de Alessandra Arce resultou de sua tese de doutorado, defendida no Programa de Pós-Graduação em Educação Escolar da UNESP de Araraquara em 2001. É um dos estudos mais completos já feitos no Brasil sobre os dois autores alemães, cujas obras ainda não foram ainda publicadas em nosso país, à exceção de um livro de Froebel, A educação do homem, lançado recentemente. Alessandra analisa o pensamento de Pestalozzi e Froebel destacando suas concepções de família, mãe e criança, bem como suas visões sobre o homem, Deus e natureza, as quais contribuem para delinear seus postulados educacionais. Como se nota, o vigor do livro consiste em não se limitar à apresentação, pura e simples, das biografias e das idéias estritamente pedagógicas dos autores; ambos são abordados em profundidade, como pensadores de uma época, em confronto com outros autores, em especial Dickens, Goethe e Schiller, e, mais ainda, são interpretados no âmbito de uma ampla e bem definida contextualização política e cultural.

A idéia central do livro - se é que se pode resumi-la em poucas palavras remete a um questionamento sobre a roupagem ideológica dos dois autores; roupagem que Alessandra Arce retira, peça por peça, desnudando o pensamento de ambos, como convém ser feito com toda ideologia. Percebe-se em Pestalozzi e Froebel a expressão mais bem acabada de uma concepção burgue- 